\title{
Evaluation of Interfractional Movement of the Seminal Vesicle and Dose Variations with IGRT Throughout the Prostate Cancer Radiotherapy
}

\author{
S. Arzu ERGEN'1, Didem C. OKSUZ', Basak IKTUEREN², Songul K. CAVDAR', \\ Alev BAKIR ${ }^{3}$, Sedat KOCA ${ }^{4}$, Fazilet O. DINCBAS ${ }^{1}$ \\ ${ }^{1}$ Istanbul University Cerrahpasa Faculty of Medicine, Department of Radiation Oncology \\ ${ }^{2}$ Istanbul University Cerrahpasa Faculty of Medicine, Department of Radiation Oncology Medical Physics \\ ${ }^{3}$ Istanbul University Cerrahpasa Faculty of Medicine, Department of Biostatistics and Medical Informatics, \\ ${ }^{4}$ Istanbul University Cerrahpasa Faculty of Medicine, Department of Radiation Oncology (retired), Istanbul, TURKEY
}

\begin{abstract}
To validate the actual cumulative doses delivered to the seminal vesicle (SV) depending on the organ movement using kV-Cone Beam $\mathrm{CT}(\mathrm{kV}-\mathrm{CBCT})$ datasets acquired during prostate image-guided radiation therapy. Ten patients with intermediate risk prostate cancer treated with IMRT were included in this study. Both the prostate and the first $2 \mathrm{~cm}$ of the SV were included in the CTV. PTV margin was $8 \mathrm{~mm}$ in all directions except posterior, where it was $5 \mathrm{~mm}$. Sixteen kV-CBCT scans per patient were used for assessments. After each kV-CBCT was matched with the planning CT based on prostate, the SV were recontoured as proximal, distal SV and both of them together (the whole SV). Actual delivered doses to the SV were assessed by means of DVH. The variations in certain dosevolume parameters were analyzed using the Student's test. Systematic and random errors of the SV and margins were assessed using the van-Herk formula. We observed that the SV movement in the anterior-posterior direction was significantly more compared to superior-inferior and left-right direction. The dose volume variations for the whole SV (D98\%, D50\%, D2\%) and the distal SV (D98\%, D95\%, D50\%) were significantly different than the planned doses. However, both the whole SV and the distal SV received the prescribed dose. Although it seems that there is a need to give larger margin to the SV in posterior direction, the actual cumulative doses delivered to SV throughout the treatment were within the prescribed dose.
\end{abstract}

Keywords: Image guided radiation therapy, Interfraction motions, kV-CBCT, Prostate cancer, Seminal vesicle

ÖZET

Prostat kanseri Radyoterapisi Sırasında Fraksiyonlar Arası Seminal Vezikül Hareketleri ve Doz Değişimlerinin IGRT ile Değerlendirilmesi

Bu çalışmanın amacı, kV-Cone Beam CT (kV-CBCT) ile görüntü kılavuzluğunda prostat kanseri radyoterapisinde organ hareketine bağlı olarak seminal veziküllerin aldığı kümülatif dozların doğruluğunun değerlendirilmesidir. Çalışmamıza IMRT tekniği ile tedavi edilmiş orta risk prostat kanserli on hasta dahil edilmiştir. Prostat ve seminal vesiküllerin ilk 2 cm'lik bölümü CTV'ye dahil edilmiştir. Prostat ve SV'e posterior yönden $5 \mathrm{~mm}$, diğer yönlerden $8 \mathrm{~mm}$ PTV marjı verilmiștir. Her hastadan 16 kV-CBCT alınmış ve SV'ye verilen marjın yeterli olup olmadığını saptamak için seçilen kV-CBCT görüntüleri ile planlama BT görüntüleri prostat referans alınarak offline eşleştirilmiştir. Seminal veziküller, proksimal-distal SV şeklinde ayrı ayrı ve her ikisi birlikte tüm SV olacak şekilde yeniden konturlanmıştır. Seminal veziküllerin aldığı doz DVH yardımı ile değerlendirilmiştir. Doz volüm histogramındaki değişiklikler Student test ile analiz edilmiştir. Sistematik ve random hatalar van-Herk formülü ile değerlendirilerek gerekli emniyet marjları bulunmuștur. Seminal vezikül hareketinin alt-üst ve sağ-sol yöne kıyasla ön-arka eksende daha fazla olduğu görülmüştür. Tüm SV için (D98\% D50,\% D2\%) ve distal SV için doz volüm değişiklikleri (D98\% D95,\% D50\%) planlanan dozlardan önemli ölçüde farklı bulunmuştur. Bununla birlikte, tüm SV ve distal SV'in tanımlanan dozu aldığı tespit edilmiştir. Çalışmamıza göre PTV marjının posterior yönde daha fazla olması gerektiği görülmesine rağmen, tedavi boyunca verilen dozlara kümülatif olarak bakıldığında SV'ler tanımlanan dozu aldığı için posterior marjin değerlerinde herhangi bir değişikliğe gidilmemiştir.

Anahtar Kelimeler: Görüntü kılavuzluğunda radyoterapi, Fraksiyonlar arası hareket, kV-CBCT, Prostat kanseri, Seminal vezikül 


\section{INTRODUCTION}

Intensity modulated radiotherapy (IMRT) technique improved both local and biochemical control and treatment related toxicity in the treatment of prostate cancer compared to 3-dimensional conformal radiotherapy. ${ }^{1-5}$ Therefore, a high dose of IMRT as the standard treatment for early and locally advanced prostate cancer has been recommended recently. For patients with intermediate and high risk prostate cancer, seminal vesicles (SV) have a higher risk of invasion and are recommended to be included to the clinical target volume (CTV). 6-7 However, the prostate and SV may be subject to inter-and intrafractional motions because of the changes in rectal and bladder filling. These displacements are important when treating prostate and SV with simultaneous IMRT irradiation technique due to the sharp dose gradients. Image guided radiotherapy (IGRT) is used to eliminate these inter-and intrafraction organ variations and set-up uncertainties during radiotherapy..$^{8-9}$

In the literature, the prostate motion has been well described while SV motion and dosimetric analysis have been relatively less well reported. ${ }^{10-18}$ When the SV are included in the target volume, independent motion and the rotation of the SV and prostate may affect the dose distribution of the SV in prostate based image guidance. Stenmark et al. showed that the displacement of the SV was different from the prostate and this movement was more in the distal part rather than the proximal part of SV. ${ }^{18}$ Although the majority of the studies analyzed the inter- or intrafraction displacements of the SV and the planning target volume (PTV) margins, there is little data about the cumulative dose distribution of SV throughout the treatment. ${ }^{15-18}$

In this study is aimed to validate the actual doses delivered to the seminal vesicle depending on the organ movement by IGRT methods.

\section{PATIENTS AND METHODS}

\section{Simulation and Planning}

Ten consecutive patients with intermediate-risk prostate cancer treated radically with IMRT technique were included in this study and $16 \mathrm{kV}$-CBCT for each patient were retrospectively evaluated. According to our institutional protocol, patients were asked to use a low-fiber diet and mild laxa- tives starting one week before the planning CT scan and during radiotherapy. In consultation with the radiation oncologist, the dose of laxative could be adjusted. They were asked to come to the department with an empty bladder and rectum and to drink $500 \mathrm{ml}$ of water 30 minutes prior to the simulation and each treatment session. The bladder volumes were checked by ultrasonography before planning CT and each treatment. These patients were positioned in supine position on a couch and immobilized with knee and foot supports. Planning computerized tomography scan (CT) of patients was taken from the level of the third lumbar vertebrae to the middle of the femurs on a G.E. Lightspeed 16 CT scanner (General Electric Healthcare, Waukesha, WI) using a slice thickness of $2.5 \mathrm{~mm}$. Volume delineations were manually contoured by a single radiation oncologist. The prostate and the proximal $2 \mathrm{~cm}$ section of the SV from the prostate-SV junction were considered CTV. Planning target volume was generated from the prostate and SV using expansion margins of $8 \mathrm{~mm}$ in all directions except posterior, where it was $5 \mathrm{~mm}$. All of the treatments were planned with either a dynamic IMRT or a VMAT technique and optimized using the Eclipse version 8.6 treatment planning system. The doses to the planning target volumes of prostate and seminal vesicles in 39 fractions of 78 Gy and 56-58 Gy, respectively and delivered with a simultaneous boost technique.

\section{Treatment}

All patients were treated for 5 consecutive weekdays on an integrated CT-LINAC system (Varian Clinac ${ }^{\circledR}$ IX model, Varian Medical Systems, Palo Alto, CA). Target localization was performed based on the prostate matching using daily half-fan $(40 \times 35 \mathrm{~cm}) \mathrm{kV}-\mathrm{CBCT}$ scans before each treatment. Bladder and rectum volumes on the CBCT were compared with the $\mathrm{CT}$ simulation scan and were assessed by the same physician. When there is deformation of the prostate due to rectal fullness, the patients were taken off the couch and asked to empty their bowel. Then again, the bladder and rectum preparation was done and treatment setup procedure was repeated from the beginning.

Alignment of kV-CBCT with planning CT images based on prostate and interpretation of images was 


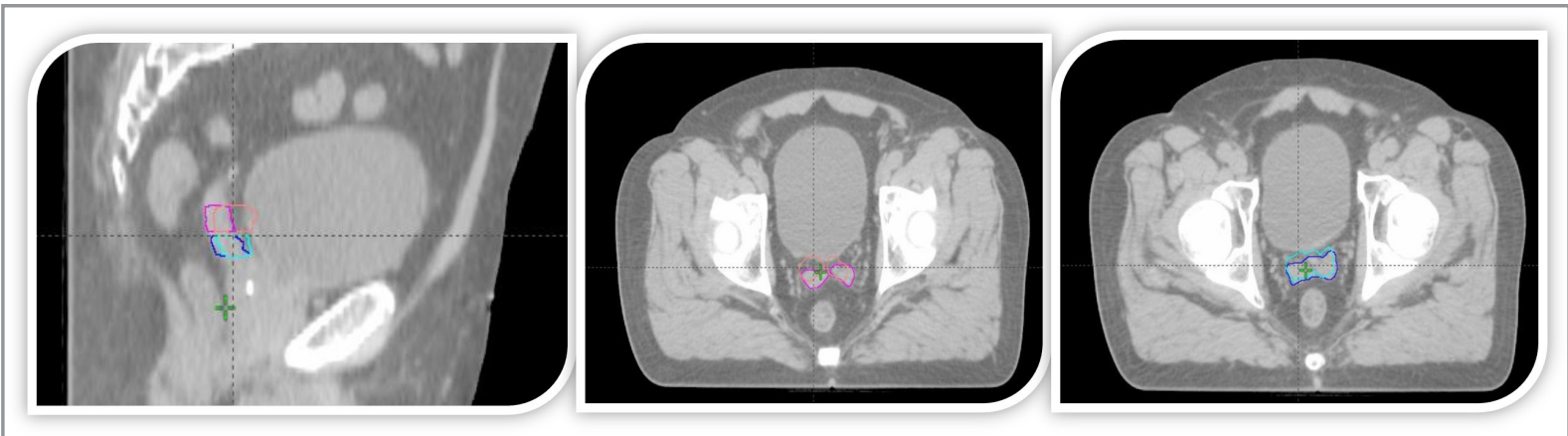

Figure 1. SV deformations projected on planning CT scan (Pink: distal SV on planning CT scan; Blue: proximal SV on planning CT scan, Orange: distal SV on at fraction 7, patients 8; Cyan: proximal SV on at fraction 7, patients 8 )

done by the same physician for all patients to eliminate interobserver variability.

\section{Data Collection and Analysis}

In this study, $16 \mathrm{kV}$-CBCTs which were taken at the first five days of treatment and then two times per week for each patient were used for assessments. After each $\mathrm{kV}-\mathrm{CBCT}$ images matched with the planning CT images based on the prostate, SV were re-contoured in three different parts: the first $1 \mathrm{~cm}$ of $\mathrm{SV}$ from the prostate-SV junction as proximal (p), second $1 \mathrm{~cm}$ from the prostate-SV junction as distal (d) and both of them as a whole (w) $\mathrm{SV}$ on planning CT images by the same physician. For the analysis, first we matched $\mathrm{kV}$-CBCT scans with CT scan based on whole SV in off-line in order to assess the PTV margin for SV. Systematic $(\Sigma)$ and random ( $\sigma)$ errors of SV and margins were

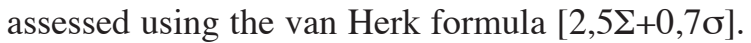

Later, offline $\mathrm{kV}-\mathrm{CBCT}$ images were matched with the planning CT based on prostate and the delivered doses were assessed with dose volume histograms (DVH).

The variations in certain dose-volume parameters of the proximal, distal parts of SV and the whole SV (D98\%, D95\%, D50\%, D2\%, D max) were analyzed using Student's test.

According to national rules do not require obtaining ethical committee approval for retrospective studies. Before the analysis our institutional board was informed that this study was conducted in accordance with the principles of Helsinki declaration and the rules of Good Clinical Practice.

\section{RESULTS}

We evaluated a total of $160 \mathrm{kV}-\mathrm{CBCT}$ scans and 480 corrected patient's data sets.

Table.1. The systematic and random errors for seminal vesicle.

\begin{tabular}{|c|c|c|c|}
\hline & \multicolumn{3}{|c|}{ Seminal vesicle } \\
\hline & Mean & $S D^{* *}$ & Range \\
\hline \multicolumn{4}{|c|}{ Systematic interval variation $(\mathrm{cm})^{\star}$} \\
\hline AP (antero-posterior) & 0.11 & 0.17 & -0.29 to 0.33 \\
\hline SI (superior-inferior) & -0.04 & 0.16 & -0.30 to 0.30 \\
\hline LR (left-right) & -0.02 & 0.13 & -0.18 to 0.33 \\
\hline \multicolumn{4}{|c|}{ Random interval variation $(\mathrm{cm})$} \\
\hline AP (antero-posterior) & 0,38 & 0,07 & $-0,1$ to 0,21 \\
\hline SI (superior-inferior) & 0,25 & 0,05 & $-0,12$ to 0,1 \\
\hline LR (left-right) & 0,27 & 0,04 & $-0,1$ to 0,1 \\
\hline
\end{tabular}




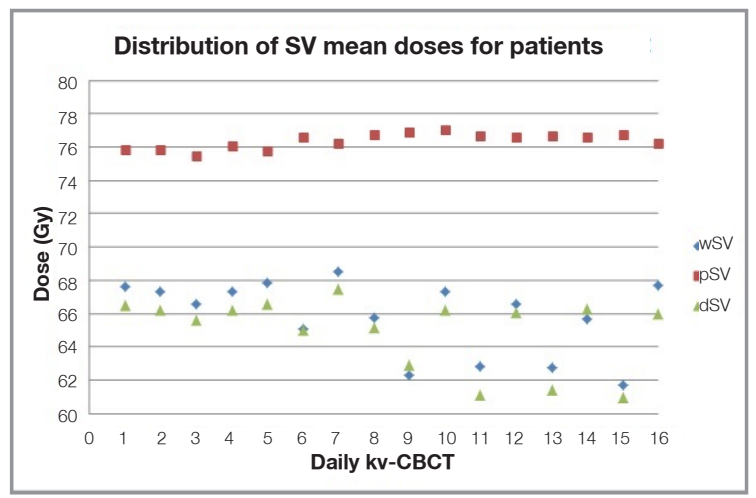

Figure 2. The distribution of mean doses of whole, proximal and the distal SV in patient 8 throughout the treatment

The interfraction displacement $( \pm \mathrm{SD})$ was $0.38 \pm$ $0.07 \mathrm{~cm}$ in anterior-posterior (AP), $0.25 \pm 0.05 \mathrm{~cm}$ superior-inferior (SI) and $0.27 \pm 0.04 \mathrm{~cm}$ in leftright (LR) axis. We observed that the movement in the anterior-posterior direction was significantly more compared to superior-inferior and left-right direction (Figure 1). In addition, the rotation of the $\mathrm{SV}$ was determined less than 0.5 degrees (mean $\left.0.01 \pm 0.03^{\circ}\right)$ in all patients. The systematic and the random errors for the $\mathrm{SV}$ are shown in Table 1.
The PTV margin of the SV according to van Herk formula was found to be $0.68 \mathrm{~cm}$ for anterior-posterior, $0.58 \mathrm{~cm}$ for superior-inferior and $0.50 \mathrm{~cm}$ for lateral directions. The dose volume variations for the whole SV (D98\%, D50\%, D2\%) and the distal SV (D98\%, D95\%, D50\%) were significantly different than the planned doses $(\mathrm{p}<0.05)$ while there was no statistically significant difference in doses of proximal SV (Table 2). However, both the whole $\mathrm{SV}$ and the proximal and the distal SV received the prescribed dose. The distribution of mean doses of the whole, proximal and the distal SV throughout the treatment in one patient are shown in Figure 2.

\section{DISCUSSION}

In the present study, we investigated the interfractional motion of SV and the influence of this movement on the actual doses delivered to SV in intermediate-risk prostate cancer patients, using $\mathrm{kV}-\mathrm{CBCT}$ data sets. SV are usually included in the CTV for the treatment in intermediate-risk and high-risk prostate cancer patients. We delineate the first $2 \mathrm{~cm}$ portion of the SV from the prostate-SV junction as a CTV; we do not include the whole $\mathrm{SV}$ in the CTV which will be translated to higher

Table.2. Comparisons of planned and actual doses to the whole, proximal and distal seminal vesicle (SV).

\begin{tabular}{|c|c|c|c|c|c|}
\hline & \multirow{2}{*}{$\begin{array}{l}\text { Planning dose } \\
\text { (Gy) }\end{array}$} & \multirow{2}{*}{$\begin{array}{l}\text { Actual dose } \\
\text { (Gy) }\end{array}$} & \multicolumn{2}{|c|}{$95 \%$ Confidence interval } & \multirow[t]{2}{*}{$p$} \\
\hline & & & upper & lower & \\
\hline \multicolumn{6}{|l|}{ Whole SV } \\
\hline Dmax & 82.11 & 81.99 & -0.2698 & 0.0265 & 0.107 \\
\hline Mean & 74.15 & 73.63 & -0.879 & -0.176 & 0.003 \\
\hline D98\% & 63.44 & 62.80 & -1.267 & -0.006 & 0.048 \\
\hline D95 \% & 64.98 & 64.50 & -1.098 & 0.128 & 0.121 \\
\hline D2 \% & 81.30 & 81.12 & -0.349 & -0.004 & 0.044 \\
\hline \multicolumn{6}{|l|}{ Proximal SV } \\
\hline Dmax. & 81.98 & 81.91 & -0.243 & 0.098 & 0.403 \\
\hline Mean & 77.82 & 77.40 & -1.356 & 0.522 & 0.382 \\
\hline D98\% & 71.59 & 71.20 & -0.995 & 0.208 & 0.199 \\
\hline D95 \% & 72.77 & 72.65 & -0.669 & 0.416 & 0.645 \\
\hline D2 \% & 81.24 & 81.21 & -0.244 & 0.173 & 0.700 \\
\hline \multicolumn{6}{|l|}{ Distal SV } \\
\hline Dmax. & 76.83 & 76.91 & -0.250 & 0.405 & 0.642 \\
\hline Mean & 70.28 & 69.89 & -0.780 & -0.011 & 0.044 \\
\hline D98\% & 63.93 & 63.20 & -1.323 & -0.125 & 0.018 \\
\hline D95 \% & 65.02 & 63.37 & -1.212 & -0.099 & 0.021 \\
\hline D2 \% & 75.45 & 75.32 & -0.472 & 0.212 & 0.455 \\
\hline
\end{tabular}


doses to the normal tissues. There is limited data about the extension of tumor invasion for the SV. The only detailed data showing the risk of invasion of the SV was reported by Kestin et al. ${ }^{6}$ They made a histopathological evaluation of 334 radical prostatectomy specimens and found that the risk of finding tumor cells was $7 \%$ beyond $1 \mathrm{~cm}$ and $1 \%$ beyond $2 \mathrm{~cm}$ from the prostate-SV junction for the entire population. For the 81 patients with SV involvement, this rate was $41 \%$ beyond $1 \mathrm{~cm}$ and $6 \%$ beyond $2.0 \mathrm{~cm}, 1 \%$ beyond $3 \mathrm{~cm}$ from the junction and they concluded that only proximal $2.0-2.5 \mathrm{~cm}$ of the SV should be included during prostate irradiation. ${ }^{6}$ In daily practice the extention of the delineation of the SV changes from center to center. Some centers prefer to include all of the SV in the CTV while some of them includes the proximal 2.0 $\mathrm{cm}$ of the SV. ${ }^{15-16}$

Currently, interfraction displacement of the prostate and SV is demonstrated with various IGRT methods. Some authors noted that the SV move independently from the prostate and more than the prostate and they suggested to give larger margins. ${ }^{16,18,19}$ In addition, Stenmark et al. reported that the SV motion was increasing towards the distal part. ${ }^{20}$ Mak et al. performed a geometric analysis both for the right and the left SV and reported that $>15 \mathrm{~mm}$ margins are needed to cover the entire left and right SV on at least $90 \%$ fractions for $90 \%$ of the patients. ${ }^{21}$ Whereas, Meijer et.al found at least $8 \mathrm{~mm}$ margin should be given for SV. ${ }^{15}$ In most of these studies, daily fiducial marker based set-up corrections had been done and the target margin had been evaluated according to the prostate movement. ${ }^{12,14,16}$

In this study, we found that the SV motion was significantly more in the AP axis and the distal part of $\mathrm{SV}$. At least $7 \mathrm{~mm}$ PTV margin was required in the posterior direction. The movement of the SV in SI, lateral directions was in the limits of our PTV margins. Mutanga et. al reported that displacements of the SV were mostly related to the deformations due to bladder and rectal filling, therefore, it is not appropriate to consider the displacements as geometrical rigid motions. ${ }^{16}$

There are few studies examining the effect of the deformation of the prostate and SV on the dose distribution. ${ }^{15,16,18}$ Therefore, we analyzed the dose changes and the cumulative dose to the SV throughout the radiotherapy which may be more realistic and superior than the rigid motion assumptions. We found that the dose volume variations for the whole SV and the distal SV were significantly different than the planned doses. However, the whole SV and proximal and distal SV doses were within the prescribed doses. This might be due to the contribution of the dose from the superior part of the prostate to the dose to the SV.

It has been shown that, the geometric and volumetric displacement of the prostate and SV is correlated with the bladder and rectum filling and intestinal motility. ${ }^{22-27}$ In addition, most of the studies concluded that the displacement of SV is more than prostate. Online and offline corrections are helpful to eliminate set-up uncertainties and to reduce systematic errors. ${ }^{23,28,29}$ In the present study, both the systematic and the random errors for SV and rotation values were relatively lower than the other reports. This may be due to the fact that we follow a strict bladder and rectum preparation protocol before the planning $\mathrm{CT}$ and during the treatment course. Some studies have noted that dietary recommendations, rectal preparation and bladder filling protocols in prostate radiotherapy could decrease the interfractional variations. ${ }^{26-27}$ Similarly, we showed that the similar protocols minimize the variations in displacement and deformation of prostate bed, bladder, and rectum with daily $\mathrm{kV}$ CBCT IGRT. ${ }^{30}$

Gill et al. investigated SV motion with cinematic magnetic resonance imaging in real time. To our knowledge, that was the first article presenting the real-time intrafractional motion of the SV. They demonstrated that the displacement of the SV was increased during treatment and was more in the superior-inferior direction. They recommended giving an additional margin to the SV if the dose is delivered based on the prostate. But the dose changes of the SV during the course of radiotherapy has not been analyzed. ${ }^{19}$ In our study, the intrafraction motion was not taken into account while most of our patients were treated with the VMAT technique, which is faster than the dynamic or static IMRT.

There are some limitations to our study. Although the same physician performed the off-line matching based on prostate and contoured SV, there 
might be mismatching due to uncertainty of the margins of the prostate and contouring variations on the CBCT images used for this analysis. The positional and volumetric changes or deformations in SV are compensated by PTV margins. We analyzed these changes in $\mathrm{x}, \mathrm{y}, \mathrm{z}$ directions and performed dosimetric effect of interfractional motion in IMRT. On the other hand, we did not evaluate the geometric uncertainties which may give additional information. ${ }^{22,23}$

In conclusion, our findings indicate that the posterior margin of the SV was insufficient to cover motion and deformation during simultaneous irradiation of the prostate and SV. However, the SV received the prescribed dose when we reviewed the cumulative DVHs. So that received dose of the seminal vesicles during the treatment has been validated. Therefore, there is no need to give relatively large margin in posterior direction. We believe that, daily IGRT with CBCT and well instructed and controlled bladder and rectum preparation facilitate to irradiate patients safely with smaller margins. However, inter-intrafractional movements should be always kept in mind, and departments should assess their margins in order to determine their own protocols.

\section{Acknowledgements:}

The CBCT of the lineer accelerator (Rapid Arc), which was provided by research funding of the University of Istanbul, Project number 36909, was used in this study.

This study was presented in part at the 56th Annual Meeting of the American Society of Therapeutic Radiology and Oncology, San Francisco September 14-17, 2014.

\section{REFERENCES}

1. Liauw SL, Weichselbaum RR, Rash C, et al. Biochemical control and toxicity after intensity-modulated radiation therapy for prostate cancer. Technol Cancer Res Treat 8: 201206, 2009.

2. Cahlon O, Zelefsky MJ, Shippy A, et al. Ultra-high dose (86.4 Gy) IMRT for localized prostate cancer: toxicity and biochemical outcomes. Int J Radiat Oncol Biol Phys 71: 330-337, 2008.

3. De Meerleer G, Vakaet L, Meersschout S, et al. Intensitymodulated radiotherapy as primary treatment for prostate cancer: acute toxicity in 114 patients. Int J Radiat Oncol Biol
Phys 60: 777-787, 2004.

4. Michalski JM, Yan Y, Watkins-Bruner D, et al. Preliminary toxicity analysis of 3-dimensional conformal radiation therapy versus intensity modulated radiation therapy on the highdose arm of the Radiation Therapy Oncology Group 0126 prostate cancer trial. Int J Radiat Oncol Biol Phys 87: 932938, 2013.

5. Matzinger O, Duclos F, van den Bergh A, et al. Acute toxicity of curative radiotherapy for intermediate- and high-risk localized prostate cancer in the EORTC trial 22991. Eur J Cancer 45: 2825-2834, 2009.

6. Kestin L, Goldstein N, Vicini F, et al. Treatment of prostate cancer with radiotherapy: should the entire seminal vesicle be included in the clinical target volume? Int J Radiat Oncol Biol Phys 54: 686-697, 2002.

7. Bayman NA, Wylie JP. When should the seminal vesicles be included in the target volume in prostate radiotherapy? Clin Oncol (R Coll Radiol)19: 302-307, 2007.

8. Kupelian PA, Langen KM, Willoughby TR, et al. Image-guided radiotherapy for localized prostate cancer: treating a moving target. Semin Radiat Oncol 8: 58-66, 2008.

9. Mayyas E, Chetty IJ, Chetvertkov M, et al. Evaluation of multiple image-based modalities for image-guided radiation therapy (IGRT) of prostate carcinoma: a prospective study. Med Phys 40: (041707): 1-9, 2013.

10. Crook JM, Raymond $Y$, Salhani $D$, et al. Prostate motion during standart radiotherapy as assessed by fiducial markers. Radiother Oncol 37: 35-42, 1995.

11. Polat B, Guenther I, Wilbert J, et al. Intra-fractional uncertainties in image -guided intensity -modulated radiotherapy (IMRT) of prostate cancer. Strahlenther Oncol 184: 668-673, 2008.

12. Aubry JF, Beaulieu L, Girouard LM, et al. Measurements of intrafraction motion and interfraction and intrafraction rotation of prostate by three-dimensional analysis of daily portal imaging with radiopaque markers. Int J Radiat Oncol Biol Phys 60: 30-39, 2004.

13. Bylund KC, Bayouth JE, Smith MC, et al. Analysis of intrafraction prostate motion using megavoltage cone beam computed tomography. Int J Radiat Oncol Biol Phys 72 : 949-956, 2008.

14. Van der Wielen GJ, Mutanga TF, Incrocci L, et al. Deformation of prostate and seminal vesicles relative to intraprostatic fiducial markers. Int J Radiat Oncol Biol Phys 72: 1604-1611, 2008.

15. Meijer GJ, de Klerk J, Bzdusek K, et al. What CTV-to-PTV margins should be applied for prostate irradiation? Four-dimensional quantitative assessment using model-based deformable image registration techniques. Int J Radiat Oncol Biol Phys 72: 1416-1425, 2008.

16. Mutanga TF, de Boer HC, van der Wielen GJ, et al. Margin evaluation in the presence of deformation, rotation, and translation in prostate and entire seminal vesicle irradiation with daily marker-based setup corrections. Int J Radiat Oncol Biol Phys 81: 1160-1167, 2011.

17. Smitsmans $\mathrm{MH}$, de Bois J, Sonke JJ, et al. Residual seminal vesicle displacement in marker-based image-guided radiotherapy for prostate cancer and the impact on margin design. Int J Radiat Oncol Biol Phys 80: 590-596, 2011. 
18. Liang J, Wu Q, Yan D. The role of seminal vesicle motion in target margin assessment for online image-guided radiotherapy for prostate cancer. Int J Radiat Oncol Biol Phys 73: 935-943, 2009.

19. Gill S, Dang K, Fox C, et al. Seminal vesicle intrafraction motion analysed with cinematic magnetic resonance imaging. Radiat Oncol 9: 174-181, 2014.

20. Stenmark MH, Vineberg K, Ten Haken RK, et al. Dosimetric implications of residual seminal vesicle motion in fiducialguided intensity-modulated radiotherapy for prostate cancer. Med Dosim 37: 240-244, 2012.

21. Mak D, Gill S, Paul R, et al. Seminal Vesicle interfraction displacement and margins in image guided radiotherapy for prostate cancer. Radiat Oncol 7: 139-147, 2012.

22. Wu Q, Ivaldi G, Liang J, et al. Geometric and dosimetric evaluations of an online image-guidance strategy for 3D-CRT of prostate cancer. Int J Radiat Oncol Biol Phys 64: 1596-1609, 2006.

23. Deurloo KE, Steenbakkers RJ, Zijp LJ, et al. Quantification of shape variation of prostate and seminal vesicles during external beam radiotherapy. Int J Radiat Oncol Biol Phys 61: 228-238, 2005.

24. Murthy $\mathrm{V}$, Shukla $\mathrm{P}$, Adurkar $\mathrm{P}$, et al. Dose variation during hypofractionated image-guided radiotherapy for prostate cancer: planned versus delivered. J Cancer Res Ther 7: 162167, 2011.

25. Kupelian PA, Langen KM, Zeidan OA, et al. Daily variations in delivered doses in patients treated with radiotherapy for localized prostate cancer. Int J Radiat Oncol Biol Phys 66: 876-882, 2006

26. Fiorino C, Di Muzio N, Broggi S, et al. Evidence of limited motion of the prostate by carefully emptying the rectum as assessed by daily MVCT image guidance with helical tomotherapy. Int J Radiat Oncol Biol Phys 71: 611-617, 2008.
27. Smitsmans MH, Pos FJ, de Bois J, et al. The influence of a dietary protocol on cone beam CT-guided radiotherapy for prostate cancer patients. Int J Radiat Oncol Biol Phys 71: 1279-1286, 2008

28. Bel A, Vos PH, Rodrigus PT, et al. High-precision prostate cancer irradiation by clinical application of an offline patient setup verification procedure, using portal imaging. Int $\mathrm{J}$ Radiat Oncol Biol Phys 35: 321-332, 1996.

29. Amer AM, Mackay RI, Roberts SA, et al. The required number of treatment imaging days for an effective off-line correction of systematic errors in conformal radiotherapy of prostate cancer- a radiobiological analysis. Radiother Oncol 61: 143150, 2001.

30. Akin M, Öksüz DC, Iktueren B, et al. Does rectum and bladder dose vary during the course of image-guided radiotherapy in the postprostatectomy setting? Tumori 100: 529-535, 2014.

\section{Correspondence}

Şefika Arzu ERGEN

Istanbul Üniversitesi Cerrahpasa Tip Fakültesi

Radyasyon Onkolojisi Anabilim Dali

34098 Fatih

ISTANBUL / TURKEY

Tel: (+90-212) $4143000 \quad$ Ext: 21774

Fax: (+90-212) 2788625

e-mail: ergenarzu@yahoo.com 